\title{
ANALISIS PENGARUH KETEBALAN WEB TERHADAP KEAMANAN BOX GIRDER AKIBAT VARIASI SUDUT KELENGKUNGAN HORIZONTAL PADA JEMBATAN
}

\author{
Michael $^{1}$ dan FX Supartono ${ }^{2}$ \\ ${ }^{1}$ Program Studi Sarjana Teknik Sipil, Universitas Tarumanagara, Jl. Letjen S. Parman No.1 Jakarta \\ Michael.325160073@stu.untar.ac.id \\ ${ }^{2}$ Program Studi Sarjana Teknik Sipil, Universitas Tarumanagara, Jl. Letjen S. Parman No.1 Jakarta \\ fxsupartono@gmail.com
}

Masuk: 03-07-2020, revisi: 08-07-2020, diterima untuk diterbitkan: 04-08-2020

\begin{abstract}
In general, bridges are made in a straight shape, but with complex geometries, topographic factors, and efforts to prevent congestion, horizontal curved bridges are used at highways and toll roads. In building a bridge, good planning is needed especially in terms of strength. However, the use of improper dimensions will cause a bridge to be over-designed or under-designed. Therefore, the purpose of this research is to determine the effect of web thickness on the safety of prestressed concrete box girder due to variations in the horizontal curvature angle on the bridge. The span length of the analysed bridge is $60 \mathrm{~m}$ with a roller-joint placement and a single span bridge type. The angular variation of the horizontal curved bridge used are $0^{\circ}, 15^{\circ}$, and $30^{\circ}$. The analysis was carried out using the MIDAS CIVIL 2020 program in accordance with the SNI $1725: 2016$ loading standard. The results of this analysis indicate that with increasing the thickness of prestressed concrete box girder web, it will cause increased stress and deflection on the bridge.
\end{abstract}

Keywords: box girder; web thickness; MIDAS CIVIL; horizontal curvature angle

\begin{abstract}
ABSTRAK
Pada umumnya jembatan dibuat dengan bentuk lurus, namun dengan adanya geometri yang kompleks, faktor topografi, dan upaya untuk mencegah terjadinya kemacetan, jembatan lengkung horizontal digunakan pada simpang susun jalan raya dan jalan tol. Dalam membangun suatu jembatan, diperlukan perencanaan yang baik terutama dari segi kekuatan. Akan tetapi, dengan penggunaan dimensi yang tidak tepat akan menyebabkan suatu jembatan menjadi over-designed atau under-designed. Oleh karena itu, tujuan dari penelitian ini adalah untuk mengetahui pengaruh dari ketebalan web terhadap keamanan prestressed concrete box girder akibat variasi sudut kelengkungan horizontal pada jembatan. Panjang bentang jembatan yang dianalisis adalah $60 \mathrm{~m}$ dengan perletakan sendi-rol dan jenis jembatan single span. Variasi sudut jembatan lengkung horizontal yang digunakan adalah $0^{\circ}$, $15^{\circ}$, dan $30^{\circ}$. Analisis dilakukan dengan menggunakan program MIDAS CIVIL 2020 sesuai dengan standar pembebanan SNI 1725 : 2016. Hasil dari analisis ini menunjukkan bahwa dengan meningkatnya ketebalan web prestressed concrete box girder, akan menyebabkan meningkatnya tegangan dan juga defleksi pada jembatan.
\end{abstract}

Kata kunci: box girder; ketebalan web; MIDAS CIVIL; sudut kelengkungan horizontal

\section{PENDAHULUAN}

Jembatan berfungsi untuk menghubungkan jalan yang terputus karena adanya rintangan dalam sebuah pembangunan jalan. Rintangan tersebut dapat berupa sungai, lembah, rel kereta api, maupun jalan yang sudah dibangun sebelumnya. Jumlah kendaraan yang terus menerus meningkat setiap tahunnya mengakibatkan jembatan tidak hanya didesain untuk melewati rintangan tersebut, melainkan juga digunakan sebagai jalan tol. Dengan adanya jembatan juga akan mempersingkat jarak tempuh dan akan menyebabkan turunnya biaya, waktu tempuh, dan tingkat kemacetan. Jembatan harus dibuat cukup kuat karena kerusakan pada jembatan dapat berdampak sangat besar terhadap kelancaran lalu lintas. Tetapi jembatan tersebut tidak berarti harus didesain terlalu kuat secara berlebihan, melainkan didesain secara ekonomis tetapi memiliki kekuatan yang cukup baik. Semakin berkembangnya dunia konstruksi, semakin banyak inovasi baru yang diciptakan untuk mendapatkan hasil yang lebih baik dan efisien, salah satunya adalah beton prategang.

Jembatan dengan beton prategang pada saat ini sudah banyak digunakan karena menghasilkan tinggi girder yang lebih rendah bila dibandingkan dengan beton bertulang biasa untuk bentang dan pembebanan yang sama dan juga 
menyebabkan penggunaan jumlah volume beton yang lebih sedikit. Pada umumnya, bagian jembatan dibedakan menjadi 2 bagian yaitu struktur atas (superstructure) dan struktur bawah (substructure). Salah satu bagian dari struktur atas yaitu girder yang berfungsi untuk menyalurkan beban berupa beban mati, beban mati tambahan, beban hidup, dan sebagainya ke struktur bawah jembatan. Girder memiliki beberapa variasi dari segi bentuk dan ukurannya yaitu I-Girder, T-Girder, U-Girder, dan Box Girder. Pada saat ini banyak jembatan prategang yang menggunakan double cellular box girder karena memiliki bentuk yang unik dan memiliki efisiensi yang tinggi.

Pada umumnya jembatan dibuat dengan bentuk lurus, namun dengan adanya geometri yang kompleks, faktor topografi, dan upaya untuk mencegah terjadinya kemacetan, jembatan lengkung horizontal digunakan pada simpang susun jalan raya dan jalan tol. Tipe jembatan ini kemudian menjadi populer digunakan karena menjadi solusi untuk transportasi (Chen \& Duan, 2000). Dengan meningkatnya sudut jembatan lengkung horizontal akan menyebabkan meningkatnya defleksi vertikal, momen, dan torsi pada jembatan (DeSantiago, et al., 2005). Jembatan lengkung horizontal menimbulkan torsi yang signifikan pada girder, dimana hal tersebut membuat desain dan konstruksi jembatan lengkung horizontal secara signifikan lebih sulit dibandingkan dengan jembatan lurus (Dong \& Sause, 2010). Dikarenakan banyaknya penggunaan jembatan lengkung horizontal, maka pada penelitian ini akan dibahas mengenai pengaruh ketebalan web terhadap keamanan prestressed concrete box girder akibat variasi sudut kelengkungan horizontal pada jembatan.

Rumusan masalah yang akan dibahas dalam penelitian ini adalah pengaruh dari ketebalan web terhadap keamanan prestressed concrete box girder akibat variasi sudut kelengkungan horizontal pada jembatan.

Tujuan dari penelitian ini adalah untuk mengetahui pengaruh dari ketebalan web terhadap keamanan prestressed concrete box girder akibat variasi sudut kelengkungan horizontal pada jembatan.

\section{Pembebanan}

\section{Berat Sendiri}

Berat sendiri adalah berat bagian tersebut dan elemen-elemen struktural lain yang dipikulnya, termasuk dalam hal ini adalah berat bahan dan bagian jembatan yang merupakan elemen struktural, ditambah dengan elemen nonstruktural yang dianggap tetap.

\section{Beban Mati Tambahan}

Beban mati tambahan adalah berat seluruh bahan yang membentuk suatu beban pada jembatan yang merupakan elemen nonstruktural, dan besarnya dapat berubah selama umur jembatan. Umumnya beban mati tambahan dapat berupa kanstin, pagar pengaman, pembatas jalan, aspal, dan lain-lain.

\section{Beban Lajur "D"}

Pembebanan Untuk Jembatan (SNI 1725:2016) menyatakan bahwa beban lajur "D" terdiri atas beban terbagi rata (BTR) yang digabung dengan beban garis (BGT) seperti yang terlihat dalam Gambar 1.

$$
\begin{aligned}
& \text { Jika } \mathrm{L} \leq 30 \mathrm{~m}: \mathrm{q}=9,0 \mathrm{kPa} \\
& \text { Jika } \mathrm{L}>30 \mathrm{~m}: \mathrm{q}=9,0\left(0,5+\frac{15}{\mathrm{~L}}\right) \mathrm{kPa}
\end{aligned}
$$

dengan $\mathrm{q}=$ intensitas beban terbagi rata $(\mathrm{BTR})$ dalam arah memanjang jembatan $(\mathrm{kPa}), \mathrm{L}=$ panjang total jembatan yang dibebani $(\mathrm{m})$.

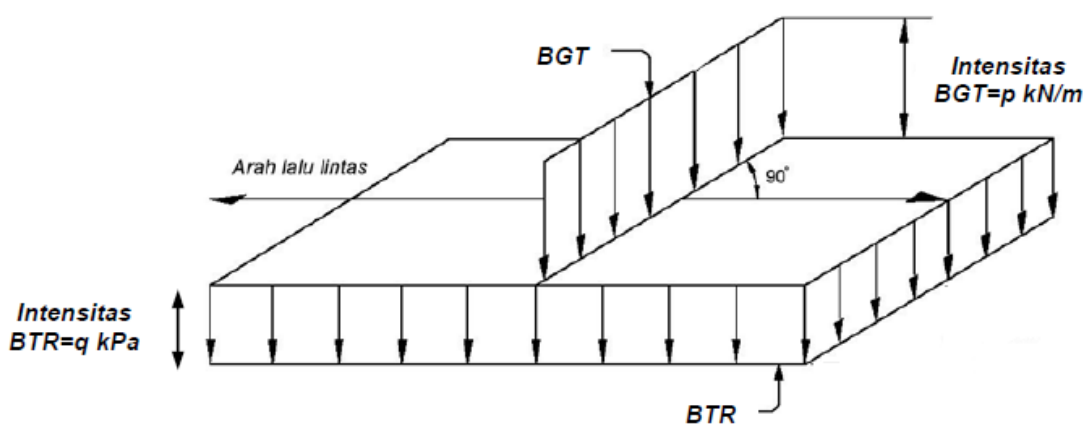

Gambar 1. Beban lajur “D” (SNI 1725:2016) 
Beban garis terpusat (BGT) dengan intensitas $\mathrm{p} \mathrm{kN/m}$ harus ditempatkan tegak lurus terhadap arah lalu lintas pada jembatan. Besarnya intensitas p adalah $49,0 \mathrm{kN} / \mathrm{m}$.

\section{Faktor Beban Dinamis}

Pembebanan Untuk Jembatan (SNI 1725:2016) menyatakan bahwa faktor beban dinamis tidak perlu diterapkan pada beban pejalan kaki atau beban terbagi rata (BTR). Faktor beban dinamis (FBD) merupakan hasil interaksi antara kendaraan bergerak dengan jembatan. Faktor beban dinamis diterapkan pada pembebanan " $D$ " untuk beban garis terpusat (BGT) dan pembebanan truk "T" untuk simulasi kejut dari kendaraan bergerak pada struktur jembatan. Pada pembebanan truk "T", faktor beban dinamis diambil 30\%. Pada pembebanan "D" untuk beban garis terpusat, faktor beban dinamis dapat dilihat pada Gambar 2.

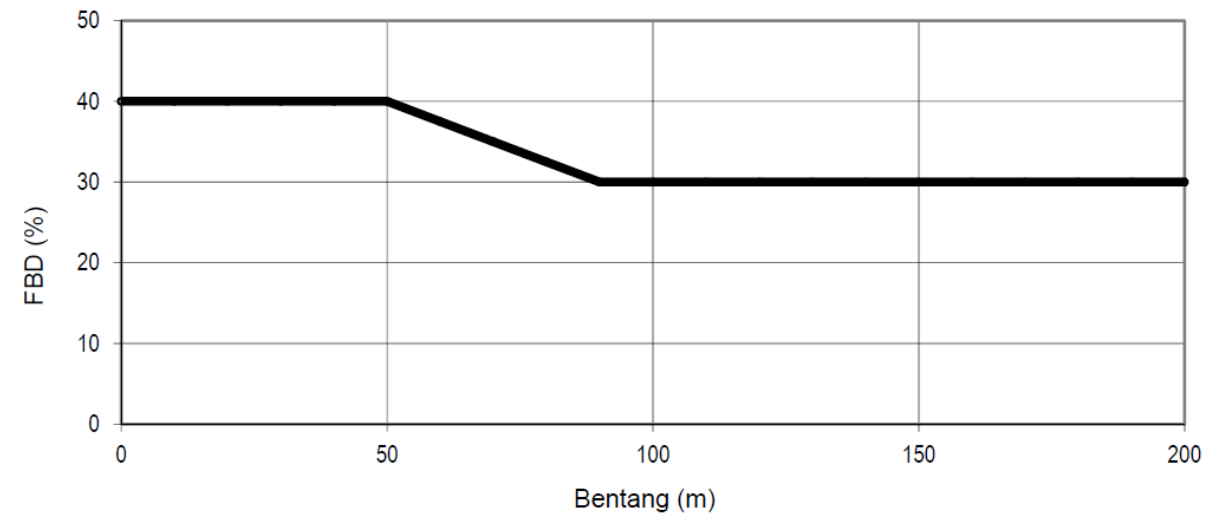

Gambar 2. Faktor beban dinamis (SNI 1725:2016)

- Untuk $\mathrm{L}_{\mathrm{E}} \leq 50 \mathrm{~m}, \mathrm{FBD}=0,4$

- Untuk $50 \mathrm{~m}<\mathrm{L}_{\mathrm{E}}<90 \mathrm{~m}, \mathrm{FBD}=0,525-0,0025 \mathrm{~L}_{\mathrm{E}}$

- Untuk $\mathrm{L}_{\mathrm{E}} \geq 90 \mathrm{~m}, \mathrm{FBD}=0,3$

Dimana $\mathrm{L}_{\mathrm{E}}=$ panjang bentang ekuivalen $(\mathrm{m})$

- Untuk bentang tunggal, panjang bentang ekuivalen diambil sama dengan panjang bentang sebenarnya.

- Untuk bentang menerus, panjang bentang ekuivalen Le dihitung berdasarkan rumus berikut:

$$
\mathrm{L}_{\mathrm{E}}=\sqrt{\mathrm{L}_{\mathrm{av}} \cdot \mathrm{L}_{\max }}
$$

dengan $\mathrm{L}_{\mathrm{av}}=$ panjang bentang rata-rata dari kelompok bentang yang disambung secara menerus, $\mathrm{L}_{\max }=$ panjang bentang maksimum dalam kelompok bentang yang disambung secara menerus. 


\section{METODE PENELITIAN}

\section{Data fisik jembatan}

- Jenis jembatan

- Panjang bentang

: Struktur Beton Prategang (Single Span)

- Lebar jembatan

: $60 \mathrm{~m}$

- Lebar lantai kendaraan

- Lebar bahu jalan

$: 9 \mathrm{~m}$

$: 2 \times 3,5 \mathrm{~m}$

- Jenis gelagar

$: 1 \mathrm{~m}$

: Double Cellular Box Girder Segmental

- Jembatan dianalisis pada sudut $0^{\circ}, 15^{\circ}$, dan $30^{\circ}$.

\section{Gelagar}

- Sistem prategang

- Mutu beton

: Beton prategang dengan sistem posttensioning

- Berat jenis

: $50 \mathrm{MPa}$

$: 25 \mathrm{kN} / \mathrm{m}^{3}$

\section{Strand}

- Jenis strand

: Seven Wire Strand ASTM A 416-06

- Diameter nominal (d) $: 15,24 \mathrm{~mm}$

- Luas nominal (Ap) $\quad: 140 \mathrm{~mm}^{2}$

- Tegangan leleh $\left(f_{p y}\right) \quad: 1675 \mathrm{MPa}$

- Tegangan putus $\left(f_{p u}\right) \quad: 1860 \mathrm{MPa}$

- Beban putus strand $\left(F_{p k}\right) \quad: 260,7 \mathrm{kN}$

- Modulus elastisitas (Es) : $200000 \mathrm{MPa}$

Untuk dimensi penampang box girder yang digunakan pada penelitian ini dapat dilihat pada Gambar 3.

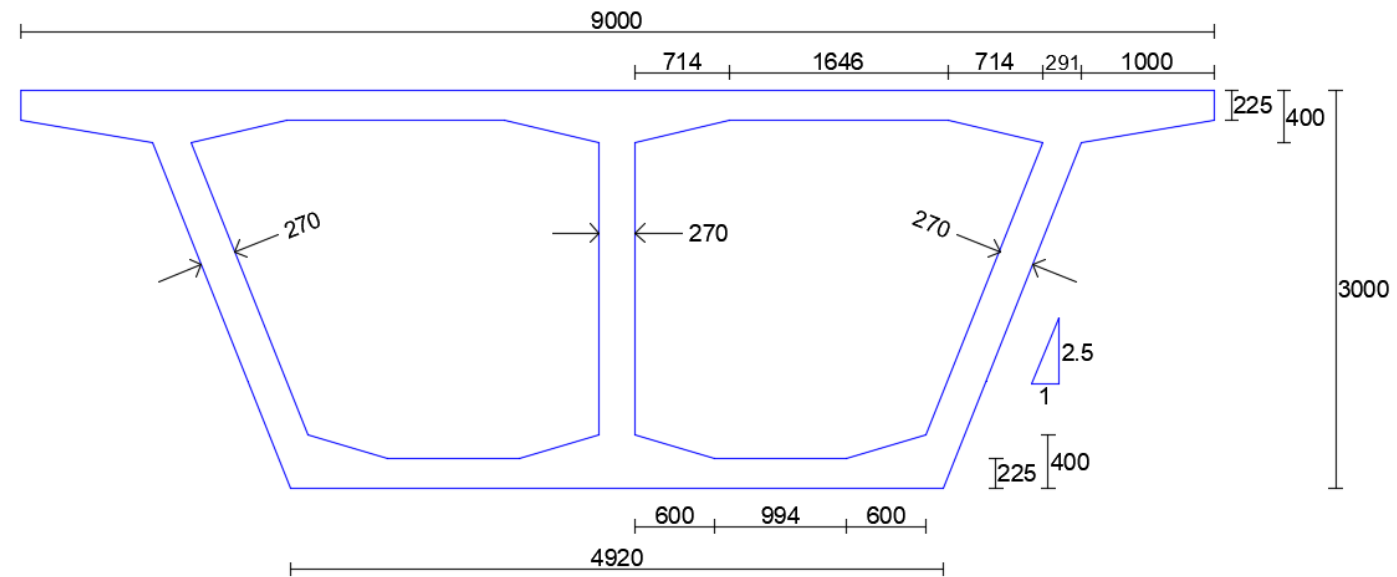

Gambar 3. Dimensi penampang box girder 
Untuk pemodelan jembatan dengan menggunakan program MIDAS CIVIL pada jembatan dengan sudut $0^{\circ}, 15^{\circ}$, dan $30^{\circ}$ dapat dilihat pada Gambar 4, Gambar 5, dan Gambar 6.

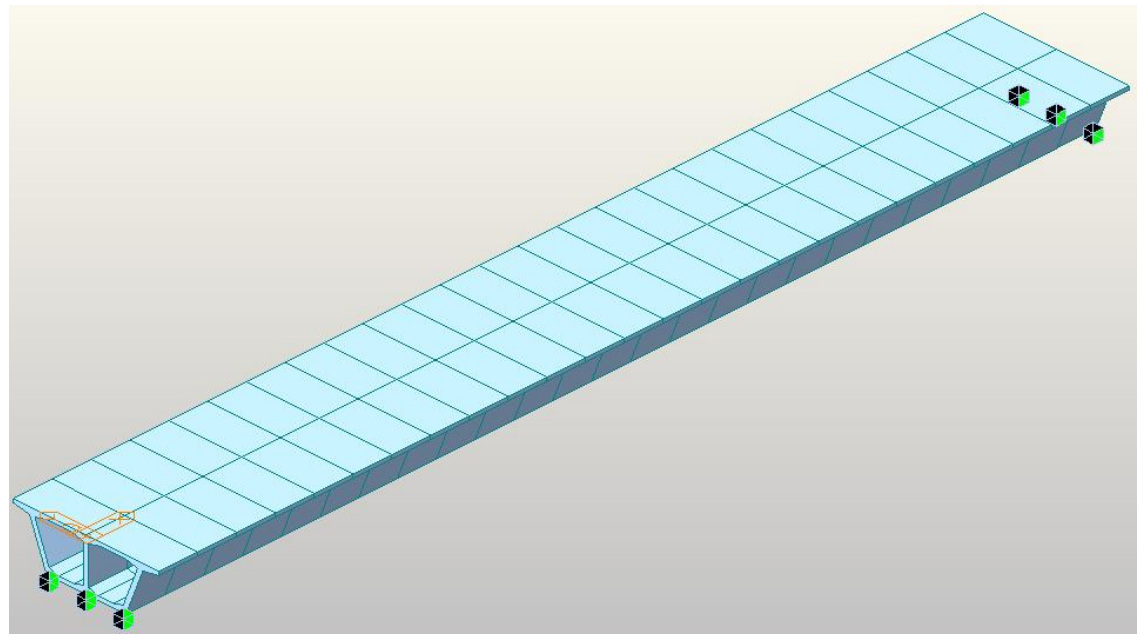

Gambar 4. Jembatan single span dengan sudut $0^{\circ}$

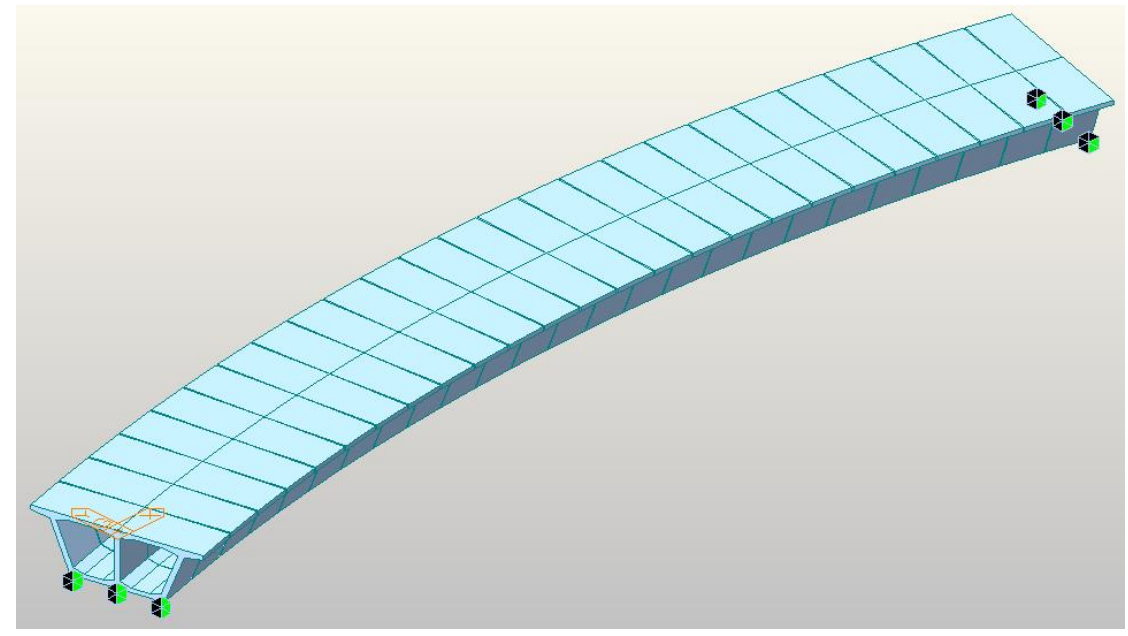

Gambar 5. Jembatan single span dengan sudut $15^{\circ}$

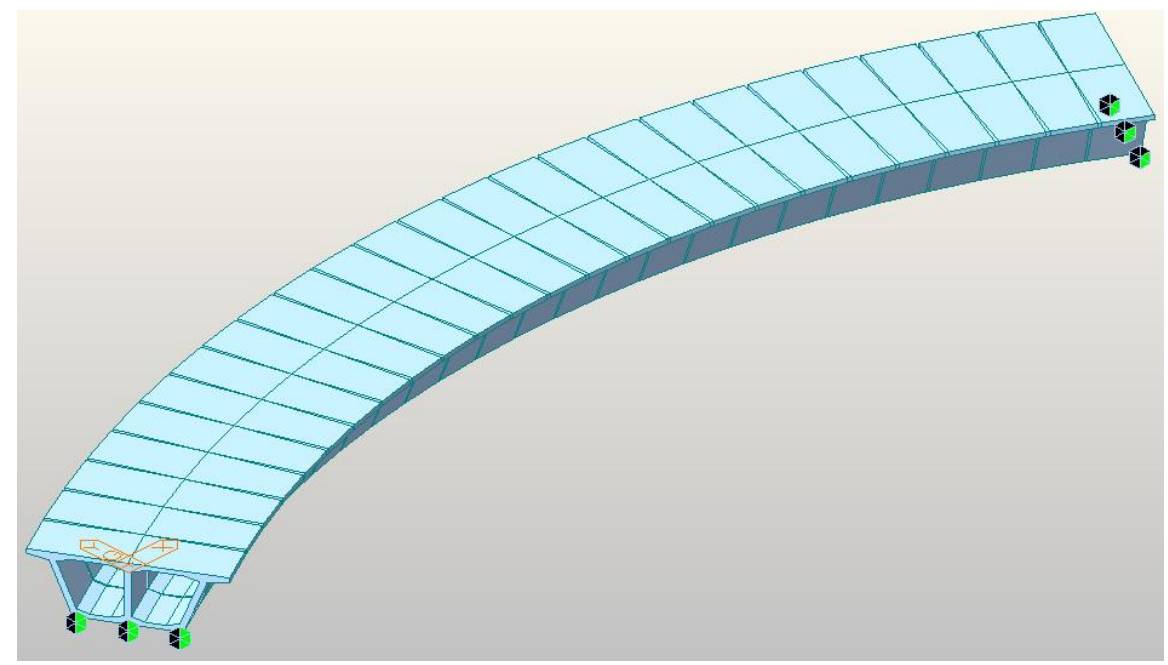

Gambar 6. Jembatan single span dengan sudut $30^{\circ}$ 
Pengertian mengenai sudut jembatan lengkung horizontal $\left(0^{\circ}, 15^{\circ}\right.$, dan $\left.30^{\circ}\right)$ dapat dilihat pada Gambar 7.

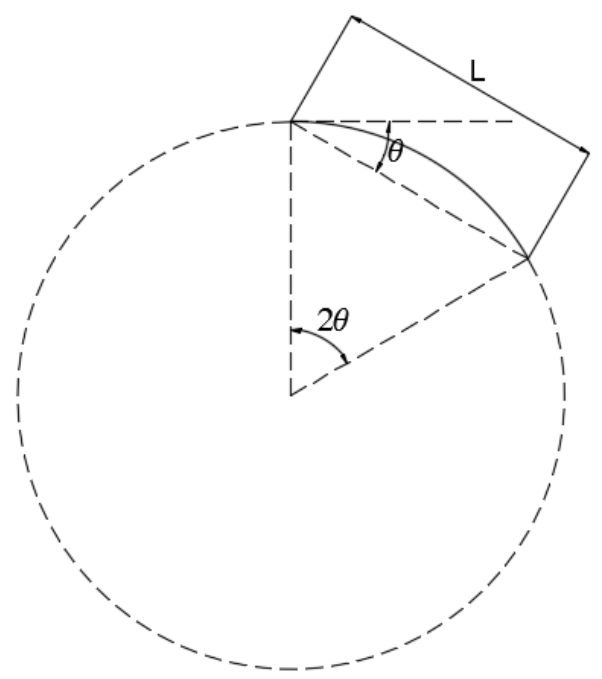

Gambar 7. Perencanaan tata letak jembatan (DeSantiago, et al., 2005)

\section{HASIL DAN PEMBAHASAN}

\section{Pembebanan}

1. Akibat Berat Sendiri

Berat box girder $=\mathrm{A} \times \mathrm{BJ}=5,9475 \mathrm{~m}^{2} \times 25 \mathrm{kN} / \mathrm{m}^{3}=148,6875 \mathrm{kN} / \mathrm{m}$

2. Akibat Beban Mati Tambahan

Perhitungan beban mati tambahan meliputi beban aspal, beban genangan air hujan, beban lampu jalan, dan beban railing.

- Beban aspal

$=\mathrm{b} \times \mathrm{h} \times \mathrm{BJ}=9 \mathrm{~m} \times 0,05 \mathrm{~m} \times 22 \mathrm{kN} / \mathrm{m}^{3}=9,9 \mathrm{kN} / \mathrm{m}$

- Beban genangan air hujan $=\mathrm{b} \times \mathrm{h} \times \mathrm{BJ}=9 \mathrm{~m} \times 0,05 \mathrm{~m} \times 9,8 \mathrm{kN} / \mathrm{m}^{3}=4,41 \mathrm{kN} / \mathrm{m}$

- Beban lampu jalan

- Beban railing $=0,1 \mathrm{kN} / \mathrm{m}$

$=1 \mathrm{kN} / \mathrm{m}$

Total beban mati tambahan

$$
=15,41 \mathrm{kN} / \mathrm{m}
$$

\section{Akibat Beban Lajur D}

Perhitungan beban lalu lintas meliputi beban terbagi rata (BTR) dan beban garis terpusat (BGT).

Contoh perhitungan beban hidup akibat beban lajur D pada bentang $60 \mathrm{~m}$.

Faktor Beban Dinamis $=0,525-0,0025 \mathrm{~L}=0,525-0,0025 \times 60=0,375$

Intensitas BTR $=q=9,0\left(0,5+\frac{15}{\mathrm{~L}}\right)=9,0\left(0,5+\frac{15}{60}\right)$

$$
=6,75 \mathrm{kPa} \times 7 \mathrm{~m}=47,25 \mathrm{kN} / \mathrm{m}
$$

$\mathrm{BGT}=\mathrm{p}=49 \mathrm{kN} / \mathrm{m} \times 7 \mathrm{~m} \times 1,375=471,625 \mathrm{kN}$

Hasil perhitungan beban hidup akibat beban lajur D pada sudut $0^{\circ}, 15^{\circ}$, dan $30^{\circ}$ secara lengkap dapat dilihat pada Tabel 1. 
Tabel 1. Beban lajur D

\begin{tabular}{ccccc}
\hline $\begin{array}{c}\text { Sudut } \\
\text { Jembatan }\end{array}$ & $\begin{array}{c}\text { Panjang Bentang } \\
(\mathrm{m})\end{array}$ & Faktor Beban Dinamis & $\begin{array}{c}\text { Intensitas BTR }(\mathrm{q}) \\
(\mathrm{kN} / \mathrm{m})\end{array}$ & $\begin{array}{c}\text { BGT }(\mathrm{p}) \\
(\mathrm{kN})\end{array}$ \\
\hline $0^{\circ}$ & 60 & 0,375 & 47,25 & 471,625 \\
$15^{\circ}$ & 60,6909 & 0,3733 & 47,0707 & 471,0325 \\
$30^{\circ}$ & 62,8319 & 0,3679 & 46,5401 & 469,1967 \\
\hline
\end{tabular}

\section{Beton}

- Kuat tekan beton prategang $\left(\mathrm{f}^{\prime} \mathrm{c}\right) \quad=50 \mathrm{MPa}$

- Kuat tekan beton saat transfer (f'ci) $=40 \mathrm{MPa}$

\section{Tegangan ijin beton}

- Tegangan ijin tekan (transfer)

$=0,6 \mathrm{f}^{\prime} \mathrm{ci}=0,6 \times 40=24 \mathrm{MPa}$

- Tegangan ijin tarik (transfer)

$=0,25 \sqrt{\mathrm{f}^{\prime} \mathrm{ci}}=0,25 \sqrt{40}=1,5811 \mathrm{MPa}$

- Tegangan ijin tekan (servis)

$=0,45 \mathrm{f}^{\prime} \mathrm{c}=0,45 \times 50=22,5 \mathrm{MPa}$

- Tegangan ijin tarik (servis)

$=0$ (Tidak boleh terjadi tegangan tarik)

\section{Hasil perhitungan momen}

Dengan melakukan perhitungan simple beam analysis berdasarkan pembebanan yang sudah dihitung, didapat nilai momen maksimum dan reaksi perletakan pada jembatan lengkung horizontal pada sudut $0^{\circ}$. Berikut ini merupakan hasil momen maksimum dan reaksi perletakan yang diperoleh pada jembatan dengan sudut $0^{\circ}$.

1. Momen Maksimum

- Berat Sendiri $\quad=66909,38 \mathrm{kNm}$

- Beban Mati Tambahan $=6934,5 \mathrm{kNm}$

- Beban Hidup $\quad=28336,88 \mathrm{kNm}$

2. Reaksi Perletakan

- Berat Sendiri $\quad=4460,63 \mathrm{kN}$

- Beban Mati Tambahan $=462,3 \mathrm{kN}$

- Beban Hidup $\quad=1653,31 \mathrm{kN}$

\section{Kebutuhan jumlah strand}

Menghitung kebutuhan jumlah strand dengan mengambil jarak dari titik berat tendon ke serat bawah box girder $=$ $400 \mathrm{~mm}$, sehingga eksentrisitas tendon pada tengah bentang $=1356,033 \mathrm{~mm}$.

1. Pada saat keadaan awal sebelum kehilangan gaya prategang

- Serat Atas Box Girder

$$
\begin{aligned}
& -\frac{P_{t}}{A}+\frac{P_{t} \times \operatorname{ex} Y_{t}}{I}-\frac{M_{t r f} \times Y_{t}}{I} \leq 0,25 \sqrt{f^{\prime} c i} \\
& -\frac{P_{t}}{5,9475 \times 10^{6}}+\frac{P_{t} \times 1356,033 \times 1243,967}{7,789923 \times 10^{12}}-\frac{66909,38 \times 10^{6} \times 1243,967}{7,789923 \times 10^{12}} \leq 1,5811
\end{aligned}
$$

$\mathrm{Pt} \leq 253394,2559 \mathrm{kN}$

- Serat Bawah Box Girder

$$
\begin{aligned}
& -\frac{P_{t}}{A}-\frac{P_{t} \times \text { e x } Y_{b}}{I}+\frac{M_{\operatorname{trf}} \times Y_{b}}{I} \geq-0,6 f^{\prime} \mathrm{ci} \\
& -\frac{P_{t}}{5,9475 \times 10^{6}}-\frac{P_{t} \times 1356,033 \times 1756,003}{7,789923 \times 10^{12}}+\frac{66909,38 \times 10^{6} \times 1756,033}{7,789923 \times 10^{12}} \geq-24
\end{aligned}
$$

$\mathrm{Pt} \leq 82484,855 \mathrm{kN}$

2. Pada saat keadaan akhir setelah kehilangan gaya prategang

- Serat Atas Box Girder

$$
-\frac{P_{e}}{A}+\frac{P_{e} \times \text { ex } Y_{t}}{I}-\frac{M_{\text {srv }} \times Y_{t}}{I} \geq-0,45 f^{\prime} c
$$




$$
-\frac{\mathrm{P}_{\mathrm{e}}}{5,9475 \times 10^{6}}+\frac{\mathrm{P}_{\mathrm{e}} \times 1356,033 \times 1243,967}{7,789923 \times 10^{12}}-\frac{102180,76 \times 10^{6} \times 1243,967}{7,789923 \times 10^{12}} \geq-22,5
$$

$\mathrm{Pe} \geq-127728,5294 \mathrm{kN}$

- Serat Bawah Box Girder

$$
\begin{aligned}
& -\frac{P_{e}}{A}-\frac{P_{e} \times e \times Y_{b}}{I}+\frac{M_{\text {srv }} \times Y_{b}}{I} \leq 0 \\
& -\frac{P_{e}}{5,9475 \times 10^{6}}-\frac{P_{e} \times 1356,033 \times 1756,003}{7,789923 \times 10^{12}}+\frac{102180,76 \times 10^{6} \times 1756,033}{7,789923 \times 10^{12}} \leq 0
\end{aligned}
$$

$\mathrm{Pe} \geq 48613,3365 \mathrm{kN}$

Diambil $\mathrm{P}_{\mathrm{e}}=48613,3365 \mathrm{kN}$ dengan asumsi telah terjadi kehilangan gaya prategang jangka panjang sehingga $\mathrm{P}_{\mathrm{e}}=$ $60 \%$ UTS.

$$
\mathrm{n}=\frac{48613,3365 \times 10^{3}}{0,6 \times 1860 \times 140}=312 \text { strand }
$$

Digunakan 21 tendon, dengan 1 tendon berisi 15 strand, maka jumlah strand yang akan digunakan $=21 \mathrm{x} 15=$ 315 strand.

\section{Letak tendon pada double cellular box girder}

Setelah mendapatkan jumlah strand dan jumlah tendon yang akan digunakan, selanjutnya adalah merencanakan posisi koordinat tendon pada box girder. Untuk posisi koordinat tendon pada tengah bentang dapat dilihat pada Gambar 8 dan untuk posisi koordinat tendon pada tumpuan dapat dilihat pada Gambar 9.

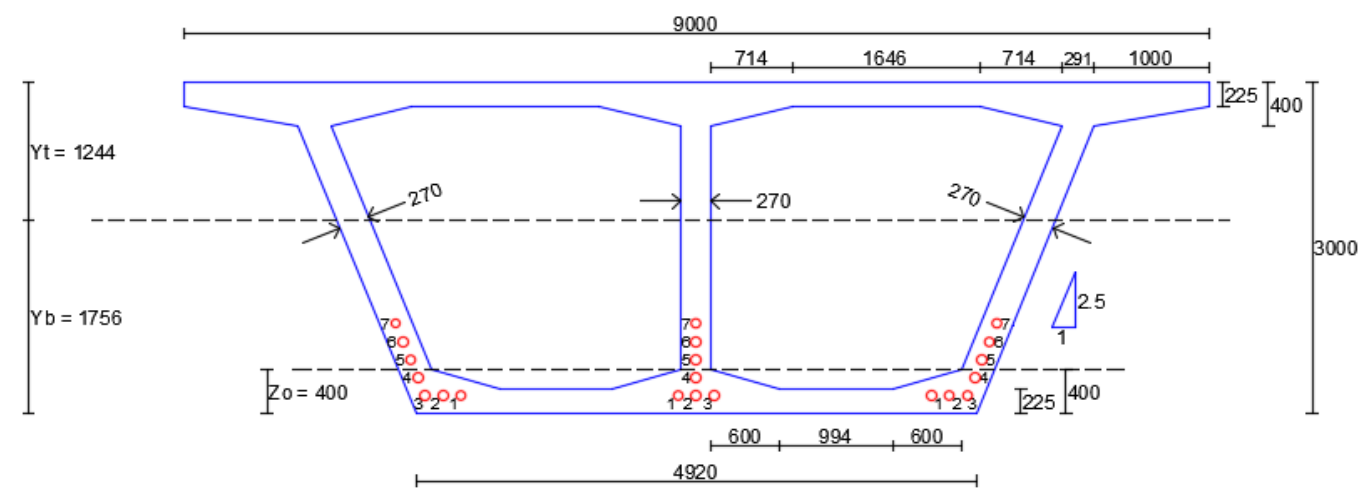

Gambar 8. Letak tendon pada tengah bentang

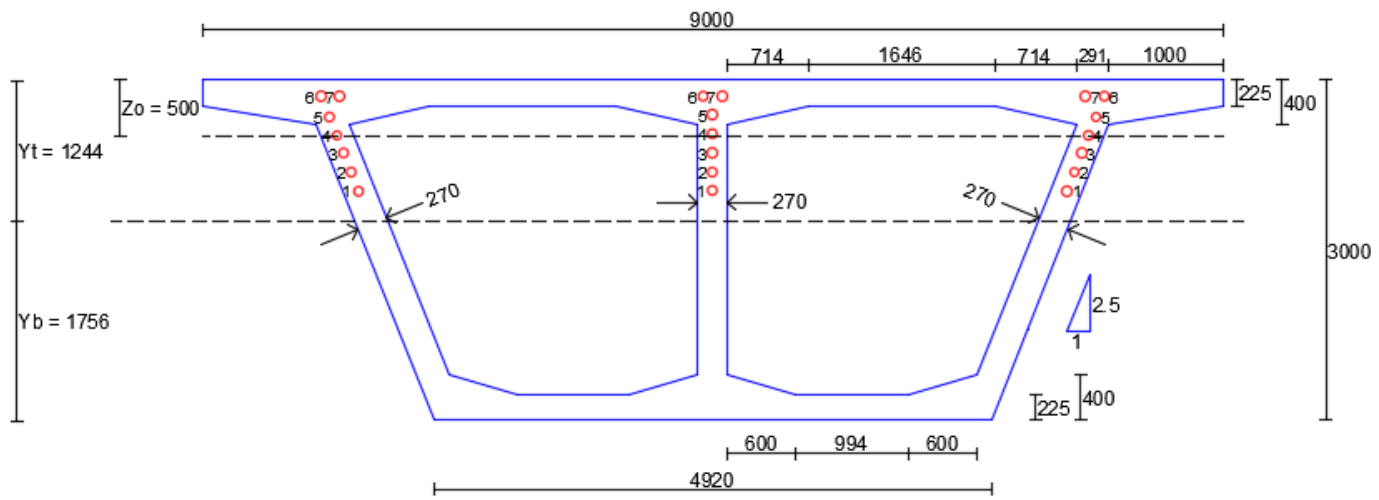

Gambar 9. Letak tendon pada daerah tumpuan

\section{Batasan ijin deformasi pada jembatan}

Berdasarkan Perencanaan Struktur Beton Untuk Jembatan (RSNI T-12-2004), dijelaskan tentang lendutan ijin pada jembatan sebagai berikut: 
1. Lendutan akibat beban rencana tidak boleh melebihi $\frac{\mathrm{L}}{250}=\frac{60000}{250}=240 \mathrm{~mm}$.

2. Lendutan akibat beban hidup tidak boleh melebihi $\frac{\mathrm{L}}{800}=\frac{60000}{800}=75 \mathrm{~mm}$.

\section{Hasil deformasi dan tegangan pada double cellular box girder}

Pada penelitian ini, hasil analisis hanya diperhitungkan pada saat post construction stage. Tabel 2 - Tabel 4 merupakan hasil deformasi dan tegangan yang terjadi pada tahap pasca konstruksi pada tengah bentang.

Perjanjian tanda yang digunakan:

- Tegangan (+) : Tegangan tarik

- Tegangan (-) : Tegangan tekan

- Deformasi (+) : Deformasi ke arah atas

- Deformasi (-) : Deformasi ke arah bawah

Tabel 2. Hasil deformasi dan tegangan pada sudut $0^{\circ}$

\begin{tabular}{cccc}
\hline \multirow{2}{*}{ Beban } & \multicolumn{2}{c}{ Tegangan $(\mathrm{MPa})$} & \multirow{2}{*}{ Deformasi $(\mathrm{mm})$} \\
\cline { 2 - 3 } & Bawah & Atas & $-96,429$ \\
\hline Berat Sendiri & 14,2283 & $-10,5867$ & $-9,994$ \\
Beban Mati Tambahan & 1,47463 & $-1,09721$ & $-38,824$ \\
Beban Hidup & 6,02585 & $-4,48359$ & 89,351 \\
Gaya Prategang & $-23,242$ & 2,35118 & $-55,896$ \\
Total & $-1,51322$ & $-13,8163$ & \\
\hline
\end{tabular}

Tabel 3. Hasil deformasi dan tegangan pada sudut $15^{\circ}$

\begin{tabular}{cccc}
\hline \multirow{2}{*}{ Beban } & \multicolumn{2}{c}{ Tegangan $(\mathrm{MPa})$} & \multirow{2}{*}{ Deformasi $(\mathrm{mm})$} \\
\cline { 2 - 3 } & Bawah & $-11,1371$ & $-109,569$ \\
\hline Berat Sendiri & 14,9506 & $-1,15425$ & $-11,356$ \\
Beban Mati Tambahan & 1,54949 & $-4,68209$ & $-43,851$ \\
Beban Hidup & 6,28571 & 2,35357 & 92,888 \\
Gaya Prategang & $-23,2383$ & $-14,6199$ & $-71,888$ \\
Total & $-0,4525$ & &
\end{tabular}

Tabel 4. Hasil deformasi dan tegangan pada sudut $30^{\circ}$

\begin{tabular}{cccc}
\hline \multirow{2}{*}{ Beban } & \multicolumn{2}{c}{ Tegangan $(\mathrm{MPa})$} & \multirow{2}{*}{ Deformasi $(\mathrm{mm})$} \\
\cline { 2 - 3 } & Bawah & Atas & \\
\hline Berat Sendiri & 17,4478 & $-13,0089$ & $-161,574$ \\
Beban Mati Tambahan & 1,80829 & $-1,34824$ & $-16,746$ \\
Beban Hidup & 7,17724 & $-5,35069$ & $-63,526$ \\
Gaya Prategang & $-23,222$ & 2,36532 & 104,46 \\
Total & 3,21133 & $-17,3425$ & $-137,386$ \\
\hline
\end{tabular}

Pada sudut $30^{\circ}$, saat kondisi servis pada tegangan bagian bawah mengalami tarik sebesar 3,21133 MPa. Karena tidak diijinkan adanya tegangan tarik pada box girder segmental, maka akan dicoba meningkatkan tebal web dari box girder. Tebal web yang akan digunakan adalah $290 \mathrm{~mm}$ dan $310 \mathrm{~mm}$.

Tabel 5. Hasil deformasi dan tegangan pada sudut $30^{\circ}$ dengan menggunakan tebal web $290 \mathrm{~mm}$

\begin{tabular}{cccc}
\hline \multirow{2}{*}{ Beban } & \multicolumn{2}{c}{ Tegangan $(\mathrm{MPa})$} & \multirow{2}{*}{ Deformasi (mm) } \\
\cline { 2 - 3 } & Bawah & Atas & \\
\hline Berat Sendiri & 17,6508 & $-13,259$ & $-163,672$ \\
Beban Mati Tambahan & 1,78196 & $-1,3386$ & $-16,524$ \\
Beban Hidup & 7,07272 & $-5,31244$ & $-62,683$ \\
Gaya Prategang & $-22,7302$ & 2,45735 & 102,462 \\
Total & 3,77528 & $-17,4529$ & $-140,417$ \\
\hline
\end{tabular}



Girder Akibat Variasi Sudut Kelengkungan Horizontal Pada Jembatan

Tabel 6. Hasil deformasi dan tegangan pada sudut $30^{\circ}$ dengan menggunakan tebal web $310 \mathrm{~mm}$

\begin{tabular}{cccc}
\hline \multirow{2}{*}{ Beban } & \multicolumn{2}{c}{ Tegangan $(\mathrm{MPa})$} & \multirow{2}{*}{ Deformasi (mm) } \\
\cline { 2 - 3 } & Bawah & Atas & \\
\hline Berat Sendiri & 17,8562 & $-13,5124$ & $-165,83$ \\
Beban Mati Tambahan & 1,75577 & $-1,32865$ & $-16,306$ \\
Beban Hidup & 6,96877 & $-5,27296$ & $-61,855$ \\
Gaya Prategang & $-22,2464$ & 2,54423 & 100,507 \\
Total & 4,33434 & $-17,5698$ & $-143,484$ \\
\hline
\end{tabular}

Hasil dari Tabel 5 dan Tabel 6 menunjukkan bahwa dengan meningkatkan tebal web akan menyebabkan meningkatnya deformasi dan tegangan tarik pada serat bawah yang semakin besar karena peningkatan momen total lebih dominan dibandingkan dengan meningkatnya inersia pada box girder. Tabel 7 merupakan tabel perbandingan antara momen total dan inersia pada box girder.

Tabel 7. Perbandingan antara momen total dan inersia

\begin{tabular}{cccccccc}
\hline Tebal Web & Inersia & \multicolumn{3}{c}{ Momen $(\mathrm{kNm})$} & \multicolumn{3}{c}{ Momen / Inersia $\left(\mathrm{kN} / \mathrm{m}^{3}\right)$} \\
\cline { 3 - 7 }$(\mathrm{mm})$ & $\left(\mathrm{m}^{4}\right)$ & $0^{\circ}$ & $15^{\circ}$ & $30^{\circ}$ & $0^{\circ}$ & $15^{\circ}$ & $30^{\circ}$ \\
\hline 270 & 7,789923 & 33367,7 & 38373,6 & 55531,4 & 4283,4 & 4926,1 & 7128,6 \\
290 & 7,885689 & 35437,4 & 40533,7 & 58004,3 & 4493,88 & 5140,17 & 7355,64 \\
310 & 7,98401 & 37558,88 & 42748,44 & 60541,81 & 4704,262 & 5354,257 & 7582,883 \\
\hline
\end{tabular}

Karena dengan melakukan peningkatan tebal web menyebabkan meningkatnya deformasi dan tegangan tarik serat bawah pada jembatan, maka akan dicoba alternatif lain yaitu dengan melakukan peningkatan tebal flange dari box girder yang mungkin memberikan hasil yang lebih baik daripada peningkatan tebal web. Tebal flange yang akan digunakan adalah $235 \mathrm{~mm}$ dan $245 \mathrm{~mm}$.

Tabel 8. Hasil deformasi dan tegangan pada sudut $30^{\circ}$ dengan menggunakan tebal flange $235 \mathrm{~mm}$

\begin{tabular}{cccc}
\hline \multirow{2}{*}{ Beban } & \multicolumn{2}{c}{ Tegangan $(\mathrm{MPa})$} & \multirow{2}{*}{ Deformasi $(\mathrm{mm})$} \\
\cline { 2 - 3 } & Bawah & $-12,9766$ & $-161,41$ \\
\hline Berat Sendiri & 17,4505 & $-1,32505$ & $-16,482$ \\
Beban Mati Tambahan & 1,78188 & $-5,25865$ & $-62,526$ \\
Beban Hidup & 7,07241 & 2,31633 & 103,058 \\
Gaya Prategang & $-22,9059$ & $-17,244$ & $-137,36$ \\
Total & 3,39889 & & \\
\hline
\end{tabular}

Tabel 9. Hasil deformasi dan tegangan pada sudut $30^{\circ}$ dengan menggunakan tebal flange $245 \mathrm{~mm}$

\begin{tabular}{cccc}
\hline \multirow{2}{*}{ Beban } & \multicolumn{2}{c}{ Tegangan $(\mathrm{MPa})$} & \multirow{2}{*}{ Deformasi $(\mathrm{mm})$} \\
\cline { 2 - 3 } & Bawah & $-12,9485$ & $-161,301$ \\
\hline Berat Sendiri & 17,4567 & $-1,30296$ & $-16,231$ \\
Beban Mati Tambahan & 1,75659 & $-5,17098$ & $-61,577$ \\
Beban Hidup & 6,97203 & 2,27151 & 101,714 \\
Gaya Prategang & $-22,6005$ & $-17,1509$ & $-137,395$ \\
Total & 3,58482 & Atan &
\end{tabular}

Hasil dari Tabel 8 dan Tabel 9 menunjukkan bahwa dengan meningkatkan tebal flange akan menyebabkan meningkatnya deformasi dan tegangan tarik serat bawah yang semakin besar karena peningkatan momen total lebih dominan dibandingkan dengan meningkatnya inersia pada box girder. Tabel 10 merupakan tabel perbandingan antara momen total dan inersia pada box girder.

Tabel 10. Perbandingan antara momen total dan inersia

\begin{tabular}{|c|c|c|c|c|c|c|c|}
\hline \multirow{2}{*}{$\begin{array}{l}\text { Tebal Flange } \\
(\mathrm{mm})\end{array}$} & \multirow{2}{*}{$\begin{array}{c}\text { Inersia } \\
\left(\mathrm{m}^{4}\right)\end{array}$} & \multicolumn{3}{|c|}{ Momen $(\mathrm{kNm})$} & \multicolumn{3}{|c|}{ Momen / Inersia $\left(\mathrm{kN} / \mathrm{m}^{3}\right)$} \\
\hline & & $0^{\circ}$ & $15^{\circ}$ & $30^{\circ}$ & $0^{\circ}$ & $15^{\circ}$ & $30^{\circ}$ \\
\hline 225 & 7,7899 & 33367,65 & 38373,64 & 55531,41 & 4283,438 & 4926,062 & 7128,621 \\
\hline 235 & 7,91827 & 34269,7 & 39327,14 & 56660,71 & 4327,928 & 4966,633 & 7155,693 \\
\hline 245 & 8,04478 & 35176,45 & 40285,14 & 57794,61 & 4372,583 & 5007,615 & 7184,117 \\
\hline
\end{tabular}




\section{KESIMPULAN DAN SARAN}

\section{Kesimpulan}

Berdasarkan hasil analisis yang telah dilakukan, maka dapat disimpulkan bahwa:

1. Dengan melakukan peningkatan tebal web pada jembatan lengkung horizontal menunjukkan hasil yang tidak maksimal, yang disebabkan oleh rasio momen terhadap kekakuan yang kurang efektif, maka dicoba alternatif lain yaitu dengan melakukan peningkatan tebal flange. Hal ini menunjukkan hasil yang lebih baik (nilai tegangan tarik berkurang) walaupun masih terdapat tegangan tarik pada jembatan.

2. Semakin meningkatnya sudut kelengkungan horizontal pada jembatan, ternyata berbanding lurus dengan meningkatnya deformasi dan tegangan pada jembatan karena bentang jembatan yang bertambah panjang.

3. Sesuai dengan hasil analisis yang dilakukan, semua deformasi yang terjadi memenuhi syarat batas ijin yang aman.

\section{Saran}

Dari hasil analisis yang telah dilakukan, maka dari itu dapat diberikan saran untuk studi selanjutnya sebagai berikut:

1. Untuk penelitian selanjutnya, dapat dicoba dengan menggunakan model serupa dengan kondisi struktur statis tak tentu.

2. Untuk penelitian selanjutnya, dapat digunakan pembebanan yang lebih bervariasi seperti beban angin, beban gempa, dan beban lainnya agar lebih mendekati kondisi yang terjadi di lapangan.

3. Untuk penelitian selanjutnya, dapat dicoba dengan mencari kebutuhan jumlah strand dengan sudut kelengkungan horizontal pada jembatan yang lebih bervariasi, dengan mempertahankan nilai ketebalan web dan flange yang digunakan.

4. Selain halnya dimensi dari box girder dan sudut kelengkungan horizontal pada jembatan, diperlukan juga perbandingan lebih lanjut dengan menggunakan box girder dengan tipe material berbahan baja.

5. Studi tentang penebalan flange adalah alternatif usulan penulis, tetapi studi tersebut belum selesai karena masih belum memperoleh hasil yang maksimal (masih terdapat tegangan tarik), sehingga masih dapat dilanjutkan untuk memperoleh hasil yang lebih baik sesuai dengan peraturan yang berlaku.

\section{DAFTAR PUSTAKA}

Chen, Wai, Fah dan Lian Duan. Bridge Engineering Handbook. CRC Press LLC, 2000.

DeSantiago, Eduardo, Jamshid Mohammadi dan Hamadallah, M, O Albaijat. "Analysis of Horizontally Curved Bridges Using Simple Finite-Element Models." Practice Periodical On Structural Design and Construction @ ASCE (2005): 18-21.

Dong, Jun dan Richard Sause. "Behavior of Hollow Tubular-Flange Girder Systems for Curved Bridges." Journal Of Structural Engineering @ ASCE (2010): 174-182.

MIDAS. Analysis For Civil Structures. Korea, 2012.

Badan Standardisasi Nasional. RSNI T-12-2004. Perencanaan Struktur Beton Untuk Jembatan. Jakarta: Badan Standardisasi Nasional, 2004.

Badan Standardisasi Nasional. SNI 1725:2016. Pembebanan Untuk Jembatan. Jakarta: Badan Standardisasi Nasional, 2016. 
Analisis Pengaruh Ketebalan Web Terhadap Keamanan Box

Michael, et al. Girder Akibat Variasi Sudut Kelengkungan Horizontal Pada Jembatan 